\title{
THE LOGIC OF COSMOPOLITANISM AND THE IDEA OF INTERNATIONAL JUSTICE
}

\author{
Isenyo Solomon Ogaba \\ Department of Philosophy, Faculty of Humanities, Management and Social Sciences. \\ Federal University Wukari, Taraba State, Nigeria \\ solomonogaba5@gmail.com
}

\begin{abstract}
Cosmopolitanism considers the citizens of states as citizens of the world. In this way, cosmopolitanism transcends the idea of the state. The question then is, can cosmopolitanism offer a conceptual grid from where to begin to theorize the possibility of principles of international justice? Does cosmopolitanism carry a credible understanding of the relationship between the self and the other which could inform a viable and valid conception of justice for states? Does the cosmopolitan perspective contain the basis for international justice? In a world constitutive of cosmopolitan individual citizens, what constitutes and represents our agency, choice and consensus? Which of us would be responsible for working out the appropriate understanding of justice and its applicability? By merely labelling all individuals as citizens of the world, it does not offer an adequate or compelling account of the mechanisms of enforceability? And finally, and perhaps most importantly, who is the other in a cosmopolitan world? These and many more are questions in which this work tends to shed light on. This work points that, in a world divided by nation states, this seems somewhat impractical as well as undesirable. This work argues that cosmopolitan account does offer a convincing moral perspective, it fails almost entirely in offering a compelling political narrative.
\end{abstract}

Keywords: Cosmopolitanism; International Justice; Citizenship; International relations.

\section{INTRODUCTION}

Cosmopolitanism remains one of the most dominant theoretical perspectives in political studies. Understood to have been worked out first in ancient Greek philosophy, this concept continues to influence mainstream politics, both in terms of its thinking as well as practice. In fact, over the last decade, cosmopolitanism has been regarded by many political thinkers as the most valid and viable conceptual framework for working out a credible alternative to the politics of exclusion, violence and segregation. Cosmopolitanism is not only seen as a framework for organizing the relation among members in the state, it is also regarded as containing a potent understanding of the relationship among states. To this extent, cosmopolitanism has developed as a forceful perspective in the theory of international relations. Cosmopolitanism is an idea which is derived from the word 'cosmopolite', which may be understood to refer to 'a citizen of the world'. The concept of citizenship has for long been understood in a territorially defined and restricted sense. A citizen is commonly referred to a person, an agent, who is recognized through a guarantee of inalienable rights. In the 
absence of rights, one is not a citizen; rather she is a subject. In both its active understanding as well as passive conceptualization, citizenship is regarded as an identity which recognizes a person as an agent, someone who is rational, and is capable of self-determination (Breckenridge et al., 2002). However, underlying this guarantee of rights and the identity of the citizen is the concept of territoriality. A citizen is one who is regarded as a member of a state, and among the features of a state is the concept of territory.

For all democratic societies, the citizen is the unit of politics - the political starting point, the conception of the self. Somewhat like citizenship, democracy is also territorially or spatially defined and limited. Democracy functions and is operated on the basis of constituencies which are territorially restricted. Since democracy is territorially restricted, it is inevitable that the identity of the self, contained in the democratic experiment would also have to be territorially marked (Obilor et al., 2018). Although cosmopolitanism may be understood to coincide and follow from the liberal tradition of political thought, it has come to develop as a distinct conceptual perspective, and one that has influenced and gained relevance in contemporary politics. And then, particularly in the theory and practice of international politics, the conceptual perspective of cosmopolitanism has been emphasized whenever there are attempts to resolve moral issues of justice and entitlement. In fact, in contemporary theorizing about international and/or global justice, the cosmopolitan perspective has emerged as dominant and perhaps that which offers a somewhat credible understanding.

The question that this study however seeks to respond to is: can we employ the idea of citizenship when working out or understanding politics in the international realm? Can the idea of a citizen serve as a valid starting place in international politics? Can we regard the citizen as an effective conception of the self for the international realm? And more importantly, can the citizen be understood as a valid conception of the self for arriving at and agreeing upon principles of justice for states? I must admit that cosmopolitanism is a deeply diverse and substantial discourse, with contributions from a wide gamut of thinkers and philosophers. Below, I only attempt to introduce cosmopolitanism by underscoring some of its dominant features and categories. I do not in any way claim, that this is an exhaustive and/or extensive account of cosmopolitanism.

\section{INTRODUCING THE LOGIC OF COSMOPOLITANISM}

Cosmopolitanism has its philosophical origins in Greek philosophy. In fact, etymologically the word cosmopolite follows from the ancient Greek word kosmopolitès, which in turn is an amalgamation of two ancient Greek words, namely cosmos (world) and polites (citizen): a cosmopolitan thereby may be understood as 'a citizen of the world'. Introducing the concept of cosmopolitanism, Chris Brown states:

In classical Greece the polis was at the centre of the lives of its citizens. The word is only weakly translated by terms such as 'city' or 'city-state'; the polis was at the centre of the religious life of its members as well as their social and political lives. Indeed, even this wide formulation is in a way misleading in so far as it separates the polis from its inhabitants: this was not the Greek way - when writing of the action of a city, Greek authors generally employed the collective term for its citizens: thus it was almost always 'the Athenians' who act rather than 'Athens'. When Aristotle refers to man as a 'political animal', the frame of reference is not that of politics in the modern sense of the term; Aristotle means that man is designed to live in society, in the city, and those who live outside the city are either beasts or gods (Brown 1992, p. 23).

These ancient conceptual roots continue to influence, reflect in and guide the agreed upon modern meaning of the word. According to this agreed upon modern meaning, a 
cosmopolitan is one who has equipped herself with the cognitive tools to transcend her local and relative cultural and social identities to associate herself with an identity which is sufficiently global and transcendental. A cosmopolitan is, in other words, someone who is accommodative of other cultures, is willing to interact with such cultures, and recognizes himself as just one among the several cultural categories that go on to make the world. As suggested by Thomas Pogge, "persons are called cosmopolitans, or cosmopolitan, when they are understanding and respectful of foreign cultures, travel widely, and can interact well with people from many societies. And cities or gatherings are called cosmopolitan when they bring together persons and groups with diverse ethnicities, languages, cultures, religions or lifestyles" (Goodin et al., 2012, p. 312).

At the outset, this meaning of cosmopolitanism may appear purely empirical or explanatory. Cosmopolitanism, according to many, reflects the way people do live their lives, when being in relation or contact with other peoples and cultures. Cosmopolitanism, however, is more than an empirical explanatory framework; cosmopolitanism is a framework for detailing how people ought to live when being in contact and in relationships with other peoples and cultures. In the words of Thomas Pogge, "cosmopolitanism involves not merely views about how things are, but primarily views about how things ought to be. Cosmopolitan positions centrally include evaluative and normative views; they assess and prescribe" (2012, p. 312). Put differently, what is particularly compelling about cosmopolitanism is its commitment and conformity to the normative. Unlike most other conceptual perspectives, which often only focus on an analysis or conceptual reading of the empirical or how things are, cosmopolitanism primarily involves normative views or questions about how things ought to be. Cosmopolitan positions centrally include evaluative and normative views; they assess and prescribe. Underlying these normative and evaluative assessments and prescriptions is the fundamental and defining value - that of recognizing and respecting all human beings as equals, mainly in terms of their moral worth. Cosmopolitanism, with its emphasis on a common universal identity of man as human being, is more akin to an ethical or moral conception. In fact, for few political thinkers, such is the moral emphasis of cosmopolitanism that it fails to be regarded as a political argument - it is, instead, an ethical cum religious inclined conception. For understanding the logic of cosmopolitanism, it would be helpful to begin with a historical trajectory of the development of cosmopolitanism.

\section{HISTORICAL TRAJECTORY OF THE DEVELOPMENT OF COSMOPOLITANISM}

The core of cosmopolitanism is the idea that all human beings, regardless of their political affiliation, are/can/should be citizens in a single community. A common place assumption is that ancient Greek philosophy was consistently anti-cosmopolitan. According to Plato and Aristotle, for instance, a man identifies himself primarily and principally as a citizen of a particular polis or city, and in doing so, he marks out his unquestioned allegiance to a specific institution and community of people. Such an allegiance would infer that he could be counted upon for cooperation and assistance in such cases as when his city is attacked, or in sustaining practices and institutions of justice as well as in defining and contributing to the common good. Put differently, the good life of a citizen, according to one interpretation of philosophers like Plato and Aristotle, is essentially linked to the fate of the city. A citizen would not be expected to share with or assist a person living outside the city (Dover 1994). Any cosmopolitan expectation of a good citizen extended only to assisting foreigners who resided in the city. This is then a territorially loaded understanding of citizenship. 
Jurnal Predestination: jurnal of Society and Culture.

Vol .1 No.2, Maret 2021

However, there are other classical Greek philosophers who did advocate cosmopolitanism, and then in profound ways. It is often argued that the first philosopher to give an explicit argument of cosmopolitanism is the $4^{\text {th }}$ Century BCE Cynic Diogenes, who was inspired by Socrates. This attribution to Diogenes develops from the belief that when "he was asked where he came from, he replied, 'I am a citizen of the world (kosmopolitès)" (Cutler 2014). This idea has been wonderfully explained in the following way: "by identifying himself not as a citizen of Sinope but as a citizen of the world. Diogenes apparently refused to agree that he owed special service to Sinope and the Sinopeans. So understood, 'I am a citizen of the cosmos' is a negative claim, and we might wonder if there is any positive content to the Cynic's world citizenship. The most natural suggestion would be that a world citizen should serve the world-state, helping to bring it about in order to enable the later work of sustaining its institutions and contributing to its common good" (Dorandi 2013, p. 54). From the cosmopolitan perspective, therefore, a person's humanness is prior and holds more political value than her citizenship.

Cosmopolitanism perhaps finds a fuller expression in the arguments of the Stoics in Rome, who extended citizenship to all human beings by virtue of their rationality (Sluga \& Horne 2010). Research suggests that this extension of citizenship to the all human beings was mainly due to the conquests which were part of the political during this time. With the conquests of the Greco-Roman world, the subsequent division of Alexander's empire knot successor kingdoms and the unification of the Roman Empire under one political power, the idea of citizenship beyond the walls and borders of the city was perhaps politically expedient and inevitable. This extension of citizenship to all human beings was also reflected in early Christianity, which upheld that while the worldly city may have a citizen's unquestioned authority, the most important work for all human beings, in accordance with the word of God, was human goodness and well-beings, which is far removed from traditional politics, and set aside in a sphere in which people of all cities and nations can become "fellow-citizens with the saints"(Dorandi 2013, p. 65). This argument is found most clearly in the writings of Augustine, who argued that citizenship of the city of God is limited to those who love God, while all others are relegated to the inferior earthly city of man.

The political basis of cosmopolitanism is resurfaces during the Enlightenment, and this resurgence can be attributed to many factors, some of which include: the increase in world trade; the reality of the spread of colonialism and the extension of empires; the travel of men across the globe and the related 'discoveries' that followed from such travel; and the emphasis on the idea of human reason and the subsequent conceptualization of a notion of human rights (Landman 2006). In fact, the idea of human rights, which has its philosophical basis in the theory of natural rights, was a major fillip to the idea of cosmopolitanism. According to the natural law theorists, nature implanted in humans, at the same time, the imperative for selfpreservation as well as feeling of fellowship, a form of sociability that unites all humans at a fundamental level into kind of world community. This understanding meant that many philosophers and intellectuals of that time regarded their membership in the cosmopolitan 'republic of letters' as more significant that their membership in the particular political states they found themselves in. This understanding was particularly evident during the American Revolution and the first years of the French Revolution (Desan et al., 2013).

With the age of Romance opening up in the eighteenth century, the terms 'cosmopolitanism' and 'world citizenship' were reworked: while these terms earlier were regarded as essentially political in terms of the idea of self-perseverance and sociability, they were now seen to indicate an attitude of open-mindedness and impartiality. A cosmopolitan, 
Jurnal Predestination: jurnal of Society and Culture.

Vol .1 No.2, Maret 2021

now, was someone who was not subservient to a particular religious or political authority, someone who was not biased by particular loyalties or cultural prejudices. In fact, the word cosmopolitan was so loosened up that it was also understood in a lighter vein to refer to one who led an urbane life-style, was fond of travelling and cherished a network of international contacts, and felt at home everywhere. Following from this understanding, philosophers like Montesquieu, Voltaire, Diderot and Hume identified themselves as cosmopolitans.

Perhaps the most dominant Enlightenment thinker on cosmopolitanism was Immanuel Kant. According to Kant, all rational beings are members in a single moral community. Such rational beings ought to be seen as analogous to citizens in the political-republican sense in that they share the characteristics of freedom, equality and independence, and that they give themselves the law, by authoring and agreeing to obey it. In his seminal work titled Towards Perpetual Peace, Kant advocated a transformation of the international legal order, which he called a 'league of nations'. It would be helpful to briefly examine Kant's arguments in Perpetual Peace (2008). In Perpetual Peace (2008), Kant offers a sets of Preliminary Articles and Definitive Articles, which together contribute to his idea of cosmopolitanism. The difference between these two however, is explicitly made clear by Kant when he argues that while Preliminary Articles offer a projection of peace, the Definitive Articles contain the prerequisites of peace. According to Kant, any attempt at peace must be based on institutionalization, mainly because in the absence of a system of guarantees, neighbours can treat each other as enemies.

It would be helpful to read these articles separately though. The Preliminary Articles, or Kant's idea of a perpetual peace between states include:

1. No conclusion of peace shall be considered valid as such if it was made with a secret reservation of the material for a future war.

2. No independently existing state, whether it be large or small, may be acquired by another state by inheritance, exchange, purchase or gift.

3. Standing armies (miles perpetuus) will gradually be abolished altogether.

4. No national debt shall be contracted in connection with the external affairs of the state.

5. No state shall forcibly interfere in the constitution and government of another state.

6. No state at war with another shall permit such acts of hostility as would make mutual confidence impossible during a future time of peace. Such acts would include the employment of assassins or poisoners, breach of agreement, the instigation of treason within the enemy state, etc (Wood 1995).

From a reading of the above mentioned articles, it is clear that although Kant advocated perpetual peace, he was conscious and convinced of the perpetuity of war. Article 6, for instance, recognizes the possibility and practicability of war among states. In fact, for Kant, "peace is not the same as the absence of war" (Diehl 2016, p. 3). These articles then, according to Kant, ought to be understood as a set of rules that may be applicable in the absence of a perpetual peace. Interestingly, the principles that these six articles are based upon are exceptionally modern and hold valid in a contemporary normative reading of international politics. Such principles include open diplomacy, non-aggression, self-determination, nonintervention, the delineation of lawful means of making war (jus in bello), and disarmament. These principles, according to Mervyn Frost, "constitute the settled norms of the modern international system", whereby a norm is regarded as settled "where it is generally recognized that any argument denying the norm (or which appears to override the norm) requires special justification" (Frost 1986 p. 121). 
Jurnal Predestination: jurnal of Society and Culture.

Vol .1 No.2, Maret 2021

According to Kant, a true and world-wide peace is possible only when states organize themselves internally according to 'republican' principles, when they organize themselves externally in a voluntary league for the sake of keeping peace, and when they respect the human rights not only of their citizens but also of foreigners. Although Kant emphasized and focused on the cosmopolitan nature of the international realm, he nevertheless remained firm on the sovereignty of the state. According to him, the league of states should not have coercive military powers because that would violate the internal sovereignty of states (Kant 2008). This position that Kant held, allowed many scholars to criticize him for being inconsistent. According to Fichte, for instance, Kant seemed to have diluted his cosmopolitan footing, since the only way to fully overcome the state of nature among states and to underscore a universal humanity and humanness was for the states to enter into a federative union with coercive powers. Fichte's arguments then were for the transformation of the concept of sovereignty, whereby states transferred part of their sovereignty to the federal-international level, but only that part that concerns their external relations to other states, while retaining the sovereignty of the states concerning their internal affairs.

Kant's idea of cosmopolitanism is contained in the second section of Perpetual Peace in the form of three Definitive Articles. Kant refers to these Definitive Articles as a kind of 'civil constitution' which all m en must adhere to. These Definitive Articles include:

1. A constitution based on the civil right of individuals within a nation (iuscivatis).

2. A constitution based on the international right of states in their relationship with one another (iusgentium).

3. A constitution based on cosmopolitan right in so far as individuals and states, coexisting in an external relationship of mutual influences may be regarded as citizens of a universal state of mankind (iuscosmopoliticum) (Kant 2008, p. 98).

In this way Kant seems to be relating the people with the state. As noted by Brown, "what Kant is doing... is bringing together two states of nature - one composed of people, the other of states. The requirement to establish a legal order, a constitution, applies to boht people and states; people are enjoined to create a civil constitution, states a lawful international order; and people and states together a system of cosmopolitan Recht" (Pogge 2012, pp.318-319).

Cosmopolitanism, as is evident, from the brief historical trajectory outlined above, not a coherent homogenous or singular perspective. Rather cosmopolitanism carries a diversity of perspectives and positions within it. This diversity of perspectives have developed from a variety of philosophical influences ranging from the Socratically inspired Cynic Diogenes and the Stoics in ancient Greece and Rome, to Immanuel Kant. However, there is a common basis to cosmopolitanism, and this common basis, according to Thomas Pogge, may be understood to be constituted by four commitments.

\section{Exploring the Idea of International Justice in the Logic of Cosmopolitanism}

In the section above, I have introduced the logic of cosmopolitanism by detailing its historical trajectory as well as it points of conceptual agreement and divergence. I now move on in this section to explore the idea of international justice in the logic of cosmopolitanism. In doing so, the questions I ask and seek to address include: what is the understanding of justice in the idea of cosmopolitanism? What is the idea of international cosmopolitan justice and how is it conceptualized for the international political realm? In what way does a cosmopolitan perspective contribute to the process and possibility of arriving at principles of justice for states? When considering what we owe to one another, are compatriots special? Do we have the same duties to non-compatriots as we have to compatriots or is there some principled way in which these two sets of duties ought to differ? 
Jurnal Predestination: jurnal of Society and Culture.

Vol .1 No.2, Maret 2021

This section, in other words, is concerned with the question: Do we as citizens have an equally binding obligation towards citizens of other territorially defined states: if yes, what is the moral and political source of such an obligation; and if no, then what can we make of our common humanity and humanness? After attempting to address these questions, I would move on in the next section to discuss the relationship between the self and the other in the cosmopolitan account of international justice. Do we as citizens of a territorially defined and closed state, have an obligation towards citizens of other equally defined and closed territorial states? In response to this question, there has been a wide variety of arguments, which for practical purposes can be classified into two simple categories. According to the first category, justice is a territorially defined value, which is permissible, legitimate and applicable only within the boundaries of the state. As such, citizens of one state do not have any obligation towards citizens of other states. This is obviously an anti-cosmopolitan position, but which would need to be explained in order to make clearer and more convincing the cosmopolitan argument. The other category follows from the cosmopolitan perspective and argues that we as citizens share a common humanity and humanness with citizens of other states, and therefore this common basis offers a justifiable and legitimate source for our obligations to them. Below I discuss in some details both these categories.

There is an important debate among egalitarian theorists about whether our concern with equality and justice should be confined to members of the same state or whether it should extend to all globally. Some theorists argue that careful consideration of notions such as reciprocity, coercion, or fair terms of co-operation mandate that we give special weighting to the interests of compatriots. Others, by contrast, argue that these concerns, when properly understood, point in the direction of equally strong duties to non-compatriots. Justice, according to the first category, is inherently and essentially limited by state/national boundaries. As mentioned above, I find it necessary to discuss the positions contained in this category and also to criticize them in order to put forward a case for a cosmopolitan account of social justice. This category holds the arguments of such scholars who argue that we, as citizens, belong to national setups and communities and any account of our global responsibilities that ignores this omits an important aspect of how we relate to one another (Gostin et al., 2010). Discussion of cosmopolitan accounts of global justice often advocate a concern for human rights. In fact, for all their differences, both nationalists and cosmopolitans frequently agree that a good way to think about some of our duties to one another is via human rights. Human rights can and does therefore serve as an important discourse for furthering discussion about our global responsibilities. Recognizing and respecting human rights are therefore important requirements for global justice. In fact much of international law does depend on the respect of human rights and related claims. Also, any attempt to evaluate the legitimacy of governments is often based on the respect and guarantee of human rights.

A cosmopolitan account of justice is understood to have guided the constitution and implementation of the United Nations' Universal Declaration of Human Rights. The United Nations Universal Declaration of Human Rights is a highly influential account of all human beings' basic entitlements and this document often plays an important role in real world debates about justice matters. According to Article 28 of the Universal Declaration of Human Rights: 'Everyone is entitled to a social and international order in which the rights and freedoms set forth in this Declaration can be fully realized' (Gostin et al., 2010 pp.318-319). The underlying idea and essence of this article is that the structure and objective of all social institutions should be geared towards the realization of the pre-eminent goal that the human rights of all human beings must be respected, realized and achieved. If this goal cannot be fully achieved, we should come as close as possible. In the words of Thomas Pogge, "the principal 
Jurnal Predestination: jurnal of Society and Culture.

Vol .1 No.2, Maret 2021

imperative governing all institutional design is that of minimizing avoidable human rights deficits - with human rights deficits possibly weighted differentially on the basis of their causal genesis, giving greater weight to any deficits that social institutions require or authorize than to deficits these social institutions merely engender or fail to prevent" (2012, pp.318). Perhaps a more viable and effective cosmopolitan account of justice, would in addition to the guarantee of effective conditions of the realization of human rights, also include a condition for the socioeconomic redistribution of goods among human beings across nation state borders. In addition to the guarantee of human rights, which respects each individual as a human being and respects the humanness of each person, it would be imperative for a cosmopolitan account of justice also to advocate a notion of justice which would aim at correction whereby social and economic goods are redistributed in order to correct historical instances of maldistribution.

Establishing such a relationship between human rights and socio-economic justice is often considered imperative as both these values are intertwined and dependent on each other. The world we live in is deeply unjust and inhuman as well as very far from realizing human rights, as billions of people, mostly in the poorer countries, lack secure access to basic foodstuffs and safe water, to minimal clothing and shelter, to physical safety, basic education and healthcare, and to vital civil and political freedoms. And these gross socio-economic injustices continue and persist even as the world continues to reinforce and claim to strengthen its commitment to human rights and humanness. This is indeed ironical. Any cosmopolitan account of justice, in order to be valid and effective, would necessarily have to develop and regard as firm the relationship between human rights and socio-economic justice. Living a human life characterized by the guarantee and respect for human rights would inevitably entail the guarantee of principles of socio-economic justice and the distribution of goods in accordance with such principles. It is for this reason that Thomas Pogge suggests a linking between the idea of human rights and the principles of socio-economic justice. Pogge puts his account of social justice cosmopolitanism in the following way:

Social institutions are unjust insofar as they foreseeably contribute to an avoidable human rights deficit. Many present institutional arrangements do so contribute. The organization of the North Korean economy foreseeably contributes to avoidable food insecurity in that country, for instance. Similarly, the rules of the World Trade Organization (WTO) regime foreseeably contribute to the massive persistence of avoidable severe poverty in the world's poorer regions - by permitting affluent countries to 'protect' their markets through tariffs, quotas, anti-dumping duties, and huge subsidies and export credits to domestic producers, for example, and by enforcing costly intellectual property rights (IPRs) in seeds and essential medicines. In the affluent countries, we typically see unfulfilled human rights abroad as an occasion for aid and assistance. We wonder whether we ought to do more to help and protect the poor and oppressed abroad and more also to enable their societies to govern themselves better. Social justice cosmopolitanism can relate us to the poor and oppressed abroad in a different way. Our failure is not merely that of helping too little, but that of designing and imposing transnational institutional arrangements that foreseeably produce and perpetuate avoidable human rights deficits on a massive scale (2012, pp.318-319).

I have above offered an account, sketchy though, of the understanding and idea of justice from a cosmopolitan perspective. The cosmopolitan understanding of justice is indeed at once, convincing as well as contentious. It is convincing because it follows from the moral standpoint that all individuals, across national borders and barriers should be considered as equal, and justice should be applicable and effective for all such individuals. Justice, according to the cosmopolitan ideal, is then clearly the 'first virtue' which cannot be overridden even by 
Jurnal Predestination: jurnal of Society and Culture.

Vol .1 No.2, Maret 2021

nationalist considerations. And this argument does appeal and sound convincing in a world which is characterized by gross inequalities and deep injustices.

However, the cosmopolitan understanding of justice is also rather contentious as it does not offer a convincing conceptual basis for overriding nationalist considerations. When does one state reserve the right to stop another state form intervening in its internal matters, even if such intervention is guised in the form of justice? Do states, when understood from the perspective of cosmopolitan justice, have such rights? Can a state interfere in the domestic matters of other states, on the grounds of social justice, without the consent of this state? Is consent a requirement for cosmopolitan justice? And can a state intervene in the internal matters of another state on grounds that it such intervention is for individual justice, without the consent of the state? It may perhaps be helpful to remember that colonialism - the intervention of dominant states in the internal matters of governance, economy and society of supposedly weaker states, was justified on grounds of a civilizing mission or as 'the burden of the white man'. Does cosmopolitan justice leave room for another equally potent possibility of colonialism? If not, the consent of the state would have to be a consideration. But a more important consideration, and one that informs the objective of this study, is what is the conception of the self and its relationship with the other that underlies the cosmopolitan perspective on international justice? what underlies the political in a cosmopolitan account of international justice? In the section below, I make an attempt to answer to some of these questions. I do so by clarifying the conception of the self and its relationship with the other from a cosmopolitan perspective of justice among states.

\section{The Cosmopolitan Conception of the Self/Other}

Cosmopolitanism as a normative idea takes the individual to be the ultimate unit of moral concern and to be entitled to equal consideration regardless of nationality and citizenship. The individual is a moral entity whose worthiness stands above and/or are compatible with the claims of nationalism and statehood. Cosmopolitan global justice then focuses on the importance of the individual as opposed to the state, community or culture. Cosmopolitans take the individual as their starting point because they believe that all human beings have equal moral worth and therefore have the right to equal moral consideration. In this sense, even if cosmopolitans disagree on how to ensure that individuals are the subject of equal moral concern, the focus of these differing approaches is the value of the individual. The cosmopolitan idea of justice therefore holds that distributive principles are not to be constrained or limited by state or national boundaries. As stated by Tan (2004), "from the cosmopolitan perspective, principles of justice ought to transcend nationality and citizenship and ought to apply equally to all individuals of the world as a whole. In short, cosmopolitan justice is justice without borders" (p. 1). The question that is relevant and that constitutes the main concern of this study is: what is the starting place of the cosmopolitan conception of global justice? Who is the self and what is his relationship with the other? Is there a credible conception of the other in a cosmopolitan account of international justice? What is the understanding of the political from a cosmopolitan reading of justice for states? In this section, I make an attempt to address these questions. In doing so, I in no way claim to be making a comprehensive statement on the idea of cosmopolitanism. In fact, as mentioned above, cosmopolitanism has its roots in ancient Greek philosophy, and any attempt to offer a comprehensive statement on it, would require a far more rigorous and focused study on its historical trajectory and political efficacy. My concern in this section, and in this study, is only to discern the validity of contending accounts of international justice by assessing their 
Jurnal Predestination: jurnal of Society and Culture.

Vol .1 No.2, Maret 2021

understandings of the conception of the self and its relationship with the other - an understanding which I believe, is central to the project of discerning and working of justice.

Cosmopolitanism and cosmopolitan accounts of international justice, both regard the individual as their starting place and focus of attention. While a conservative reading of international relations or even international politics would regard the state as the major and central player in the international realm, cosmopolitanism sees the individual as the main actor and initiator of politics. As mentioned above, cosmopolitanism regards all individuals as 'citizens of the world'. The world is therefore not constituted and made up of states; rather it is constituted by individuals. Such individuals, in spite of being divided by the borders of nation states, do share a common humanness and humanitarian affinity which enables them to demonstrate a sense of care and justice for their fellow human beings, and therefore which provides a supposedly fertile ground for the determination and effective application of international justice. For the cosmopolitan account of international justice, therefore, the individual is the conception of the self. The self, in other words, is the individual who is devoid of any historical understanding, cultural markers and nationalist sentiments.

Such an individualized reading of the citizen is indeed a rather potent tool in questioning and breaking the structure of traditional hierarchies which have been the basis for gross unjust inequalities. Aristocracy or even slavery for instance, were based on traditional notions of hierarchy and collective political life, which denied many people the right and freedom to live decent and respectable lives free of the injustices that were regarded as essentially and extremely violent. Such collectivises and communities, as argued by Charles Taylor, were worked out and legitimized on the basis of the 'politics of honour' which denied equal dignity and respect to all its members. ${ }^{47}$ For instance, the use of the terms 'Lord' and 'honourable' were clearly intended to work out a separate class of people who were considered different if not higher than others. The individual is a self who is devoid of ends, attachments and identities. The individual is one who stands at a distance from all conceptions of the good and is considered free to choose his/her ends and revise them in accordance with his/her interests. It is this replacement of the category of community with the idea of the individual which allows the western society to move from the usage of terms such as 'Lord' and 'Lady' to 'Mr' and 'Miss/Mrs'. Undoubtedly, individualism has contributed immensely to the project and promise of an equal and just social setup. However, this understanding of individualism has been questioned, mainly by theorists who concern themselves with working out a theory or principles of justice. For such theorists, the problem with individualism is not its radicalizing or equalizing ethos; the problem rather is that the idea of individualism cannot be regarded as a credible and/or valid understanding of the self as it does not carry or give space to a valid account of the other..

Cosmopolitanism is then influenced by liberal individualism when it holds that all individuals as citizens of the world. Also, by placing the individual above cultural and nationalist considerations, cosmopolitanism does suggest that it understands the self to be distanced if not devoid of all attachments and conceptions of the good. The question then is: does a cosmopolitan account of international justice hold a valid conception of the self and the other.

From the above analysis, it is somewhat evident that few, if any cosmopolitan thinker has attended to working out or beginning their understanding from a conception of the self/other. Almost all, if not all, cosmopolitan thinkers begin with the assumption, somewhat unsubstantiated, that all individuals are citizens of the world. However, if all individuals are citizens of the world, who constitutes the other? Who is the claimant of justice in a setup where everyone is an equal individual? In fact, why does the imperative of justice arise in such a 
Jurnal Predestination: jurnal of Society and Culture.

Vol .1 No.2, Maret 2021

setting where everyone is treated alike, similarly and without any sort of discrimination or disadvantage? In fact, most cosmopolitan thinkers have acknowledged that they are not concerned with the question of the starting place. One of the many problems with the cosmopolitan account of justice and international justice, both, is that it assumes an inherent and essential link between equality and need (Cupit 2012). By regarding all persons as individuals and all individuals as equals, it assumes that the concern of need (as different from want) is sufficiently addressed. Justice, however, is premised not so much on the politics of equality as it is on the politics of need and the distribution of goods to equally satisfy everyone's need. Since cosmopolitanism identifies equality with need, it does not conceptualize the necessity or imperative to work out a conception of the other. This perhaps, I believe, is the weakest part of the cosmopolitan argument.

In the real realm of international politics, the cosmopolitan account has received its most formidable challenge from the rise of nationalist aspirations. While the process of globalization in recent decades seems to lend some credence to the cosmopolitan ideal, the last decade has witnessed the rise of nationalism and group-based identity politics which seems to contradict the aspirations of cosmopolitan justice. Thus Samuel Scheffler observes that "both the particularist and globalist ideas have become increasingly influential in contemporary politics, and one of the most important tasks of contemporary liberal theory is to address the twin challenges posed by particularist and globalist thinking" (Cupit 2012, p. 602). Similarly Andrew Vincent concludes his study on nationalism wondering whether the universalist aspiration of contemporary political philosophy can properly account for the particularistic attachments that are basic to any meaningful human life. While Vincent advises due vigilance against nationalism and other forms of group-based allegiances, which have and continue to be the major cause of violence, violation, denial and disrespect, which in turn contributes to injustice, he also rightly worries that universalist political philosophies tend to quickly "dismiss groups and group-based claims as irrelevant or incoherent" (Vincent 1997, p. 2).

One central challenge to the cosmopolitan idea of distributive justice is that it is unable to accommodate and appreciate the special ties and commitments that characterize the lives of ordinary individuals and that are of value to them. Contemporary accounts of cosmopolitan justice have been criticized for failing to take seriously the ties and commitments of nationalism and patriotism. An equally central limitation of the cosmopolitan project is its failure to offer a structure or system of enforceability. Even if we all agree to the idea that we all are citizens of the world and that we share a common humanity and humanness, who is responsible for enforcing this idea? Politics is often incomplete without mechanisms of enforceability and implementation. The regime of human rights, which is also advocated by cosmopolitanism, has been sufficiently criticized for the lack of measures and systems of enforceability, which render it somewhat toothless. A cosmopolitan account of the self, in the absence of a well-thought structure and system of enforcement would appear almost if not entirely like a paper tiger.

The main limitation of the cosmopolitan perspective is its failure to conceptualize a sufficiently political conception of the self and establish a similarly political relationship between the self and the other. Justice, as mentioned above, often starts from the other. Here, the other is created through the process of othering which is often carried out and sustained by the self. According to the cosmopolitan conception of justice, we are all individuals, and therefore similarly constituted. There is no politically relevant difference between us. As pointed out by Brown, "cosmopolitanism is compatible with a rejection of politics" (Brown 1994, p. 24). This would obviously raise the question: who is the subject of justice in a cosmopolitan conception of justice? I must state that I do understand the individualizing 
Jurnal Predestination: jurnal of Society and Culture.

Vol .1 No.2, Maret 2021

initiative of liberalism to be a rather radical one. However, it fails to offer a plausible understanding of justice.

\section{CONCLUSION}

I have discussed the logic of cosmopolitanism as well as examined the cosmopolitan account of international justice. Cosmopolitanism, as mentioned above, may be traced back to ancient Greek philosophy, some strands of which advocated the idea of a citizen across and beyond the state. Cosmopolitanism is then a political idea that holds that persons are citizens of the world, and not limited and constrained by the idea of the nation state or the premise of nationalism. Cosmopolitanism has been characterized by a diversity of positions, and yet they are all hold this understanding of a common personhood across national boundaries. This, apparently, may be considered to inform the possibility of a viable theory of international justice. In fact, many thinkers who agree with the cosmopolitan perspective argue that this perspective offers the most viable conceptual premise on which to work out and agree upon a global principle of justice for states.

A major concern of all these different understandings of justice is the relationship between the cosmopolitan idea of the global citizen and the nationalist claims of nation states. In other words, what is the relationship between a person's cosmopolitan belonging and her nationalistic aspirations? Almost all cosmopolitans argue that cosmopolitanism and nationalist are inherently compatible. That there is no conflict between a person's cosmopolitan identity as a citizen of the world and her belonging to a particular national community. Cosmopolitanism often gets mistaken or misunderstood for a project arguing in favour of world government. This however, is not entirely true. Cosmopolitanism does not favour a world government per se. As noted by Brown, "cosmopolitanism has no necessary connection with the desire for some kind of world government.... What is crucial to a cosmopolitan attitude is the refusal to regard existing political structures as the source of ultimate value. Second, cosmopolitanism is a universalist principle but all universalist principles are cosmopolitan. In the classical period the Greek cities were universally a source of value, but the values were differentiated" (Brown 1994, p. 24). While the cosmopolitan account does offer a convincing moral perspective, it fails almost entirely in offering a compelling political narrative. The cosmopolitan world is clearly and categorically an apolitical world - a world rid of the conflicts and contestations that constitute the heart of the political, and which in turn invoke the imperative and raison d'etre of justice.

\section{REFERENCES}

Breckenridge, C. A., Chakrabarty, D., Bhabha, H. K., \& Pollock, S. (Eds.). (2002). Cosmopolitanism (Vol. 12, No. 3). Duke University Press.

Brown, C. (1992). International relations theory: New normative approaches (Vol. 327). Hemel Hempstead: Harvester Wheatsheaf.

Brown, C. (1994). 'Turtles All the Way Down': Anti-Foundationalism, Critical Theory and International Relations. Millennium, 23(2), 213-236.

Cupit, G. (2012). Review of'Global Justice: A Cosmopolitan Account', by Gillian Brock.

Cutler, I. (2014). Cynicism from Diogenes to Dilbert. McFarland.

Desan, S., Hunt, L., \& Nelson, W. M. (Eds.). (2013). The French Revolution in Global Perspective. Cornell University Press. 
Jurnal Predestination: jurnal of Society and Culture.

Vol .1 No.2, Maret 2021

Diehl, P. F. (2016). Exploring peace: Looking beyond war and negative peace. International Studies Quarterly, 60(1), 1-10.

Dorandi, T. (Ed.). (2013). Diogenes Laertius: Lives of eminent philosophers (Vol. 50). Cambridge University Press.

Dover, K. J. (1994). Greek popular morality in the time of Plato and Aristotle. Hackett Publishing.

Goodin, R. E., Pettit, P., \& Pogge, T. W. (Eds.). (2012). A companion to contemporary political philosophy (Vol. 105). John Wiley \& Sons.

Gostin, L. O., Heywood, M., Ooms, G., Grover, A., Røttingen, J. A., \& Chenguang, W. (2010). National and global responsibilities for health. Bulletin of the World Health Organization, 88, 719-719a.

Kant, I. (2008). Toward perpetual peace and other writings on politics, peace, and history. Yale University Press.

Landman, T. (2006). Studying human rights. Psychology Press.

Obilor, O. I., Iwundu , K., Okoroafor, F. O., Chima, E., \& Bello, M. B. (2018). Democracy and National Development: A Focus on Nigeria. GNOSI: An Interdisciplinary Journal of Human Theory and Praxis, 1(2), 1-8.

Sluga, G., \& Horne, J. (2010). Cosmopolitanism: Its pasts and practices. Journal of World History, 369-373.

Tan, K. C. (2004). Justice without borders: Cosmopolitanism, nationalism, and patriotism. Cambridge University Press.

Vincent, A. (1997). Liberal nationalism and communitarianism: an ambiguous association. The Australian Journal of Politics and History, 43(1), 14.

Wood, A. (1995, February). Kant's project for perpetual peace. In Proceedings of the Eighth International Kant Congress (Vol. 1, No. Part 1, pp. 3-18). 